\title{
Study on Microstructure and Properties of Zr-Si-N Films with Different Nitrogen Partial Pressures
}

\author{
Wang Jianfeng $^{1}, \quad$ Ma Dayan ${ }^{1}, \quad$ Song Zhongxiao ${ }^{1}, \quad$ Tang $\mathrm{Wu}^{2}, \quad \mathrm{Xu} \mathrm{Kewei}^{1}$ \\ ${ }^{1}$ State Key Laboratory for Mechanical Behavior of Materials, Xi'an Jiaotong University, Xi'an 710049, China, ${ }^{2}$ State Key Laboratory of \\ Electronic Thin Films and Integrated Devices, University of Electronic Science and Technology of China, Chengdu, 610054, China
}

\begin{abstract}
Zr}-\mathrm{Si}-\mathrm{N}$ films were prepared by radio frequency powered reactive magnetron sputtering at different $\mathrm{N}_{2}$ partial pressures. The influences of $\mathrm{N}_{2}$ partial pressure on the microstructure and properties of $\mathrm{Zr}$-Si-N films were studied. The results reveal that the $\mathrm{Zr} / \mathrm{Si}$ ratio decreases and the sheet resistance increases as the $\mathrm{N}_{2}$ partial pressure increases. The microstructures of $\mathrm{Zr}-\mathrm{Si}-\mathrm{N}$ films are composed of nano-crystallite $\mathrm{ZrN}$ embedded into amorphous matrix of $\mathrm{SiN}_{x}$ phase and a small quantity of $\mathrm{Zr}_{2} \mathrm{Si}$ produced at low $\mathrm{N}_{2}$ partial pressure. The appearance of $\mathrm{Zr}_{2} \mathrm{Si}$ phase is related to the low nitridation level. The microhardness of $\mathrm{Zr}-\mathrm{Si}-\mathrm{N}$ film decreases with the increase of $\mathrm{N}_{2}$ partial pressure at the $\mathrm{N}_{2}$ partial pressure of $0.03 \mathrm{~Pa}$, the microhardness of $\mathrm{Zr}-\mathrm{Si}-\mathrm{N}$ films is possessed of maximum value of about $22.5 \mathrm{GPa}$. The phenomenon that high $\mathrm{N}_{2}$ partial pressure results in low microhardness in $\mathrm{Zr}-\mathrm{Si}-\mathrm{N}$ films may be related to the lattice distortion induced by the addition of $\mathrm{Si}$.
\end{abstract}

Key words: Zr-Si-N films; magnetron sputtering; microstructure; properties

Transition metal nitrides find wide applications in many sectors, such as diffusion barriers in microelectronics, hard wear resistant coatings on cutting tools, or as corrosion and abrasion resistant layers on optical and mechanical components ${ }^{[1]}$. Recently, it is frequently reported that some additives such as Al and Si can improve the properties of nitride coatings ${ }^{[2]}$. In microelectronic field, ternary thin films, such as Ti-Si-N ${ }^{[3]}$ and Ta-Si-N ${ }^{[4]}$ films also exhibit excellent diffusion barriers performance. Veprek and Reiprich ${ }^{[5]}$ suggested that composite materials consisting of crystalline refractory transition metal nitrides such as $\mathrm{ZrN}, \mathrm{NbN}, \mathrm{VN}$, $\mathrm{W}_{2} \mathrm{~N}$ and TiN with amorphous $\mathrm{Si}_{3} \mathrm{~N}_{4}$ are the most promising candidate. Although several investigations on the barrier performances and thermal stabilities of $\mathrm{Zr}-\mathrm{N}^{[6]}$ and $\mathrm{Zr}-\mathrm{Si}-\mathrm{N}^{[7]}$ films were conducted, little research is focused on the microstructure and properties of $\mathrm{Zr}-\mathrm{Si}-\mathrm{N}$ films with different deposition conditions. The present work reveals $\mathrm{Zr}-\mathrm{Si}-\mathrm{N}$ films deposited onto Si wafers and mainly reports the effects of nitrogen partial pressure on the microstructure and properties of $\mathrm{Zr}-\mathrm{Si}-\mathrm{N}$ films.

\section{Experimental}

$\mathrm{Zr}-\mathrm{Si}-\mathrm{N}$ films were prepared in ultrahigh vacuum reactive magnetron sputtering equipment. The mirror-polished Si (100) wafers were used as substrates and cleaned ultrasonically before they were put into vacuum chamber. The base pressure of vacuum chamber was lower than $10^{-5} \mathrm{~Pa}$ and the substrates were firstly cleaned by bombardment of Ar ion. The composite targets consisted of zirconium plate (purity with $99.9 \%, \Phi 75 \mathrm{~mm} \times 5 \mathrm{~mm}$ ) and two Si chips (purity with $99.999 \%, 10 \mathrm{~mm} \times 10 \mathrm{~mm} \times 0.6 \mathrm{~mm}$ ) that were stuck on the zirconium plate. The target was sputtered in a mixture of argon and nitrogen (purity with 99.999\%) to deposit the $\mathrm{Zr}-\mathrm{Si}-\mathrm{N}$ films. During deposition, the sputtering pressure was $0.3 \mathrm{~Pa}$ and the nitrogen partial pressure was 0.03, 0.06 and $0.09 \mathrm{~Pa}$ respectively. The bias voltage applied on the substrates was $-100 \mathrm{~V}$. The RF power was 200 $\mathrm{W}$ and the distance between the target and the substrate was fixed at $80 \mathrm{~mm}$.

The film composition was determined by an Energy Dis-

Received date: July 12, 2008

Foundation item: Supported by National Basic Research Program (973 program) (No. 2004CB619302), the National Natural Science Foundation of China (No. 50601020, 50601005) and Applied Materials (Xi'an) Foundation (No. XA-AM-200617)

Biography: Wang Jianfeng, Candidate for Ph. D., State Key Laboratory for Mechanical Behavior of Materials, Xi an Jiaotong University, Xi'an 710049, P. R. China, Tel: 0086-29-82668614, E-mail: Wangjianfeng@mail.xjtu.edu.cn; Corresponding Author: Ma Dayan, E-mail: madayan@mail.xjtu.edu.cn

Copyright ( 12009 , Northwest Institute for Nonferrous Metal Research. Published by Elsevier BV. All rights reserved. 
persive Spectroscopy (Oxford INCA X-sight). The X-ray diffraction (Regaku D/max-3A) patterns were obtained with $\mathrm{CuK} \alpha$ radiation. The microstructure was examined with a Transmission Electron Microscope (JEM-200). The chemical bonding state of $\mathrm{Zr}-\mathrm{Si}-\mathrm{N}$ films was characterized by X-ray Photoelectron Spectroscopy (PHI-5702) using Al-K $\alpha$ radiation. The sheet resistance and microhardness of $\mathrm{Zr}-\mathrm{Si}-\mathrm{N}$ films was investigated with four-point probe meter (SDY-4) and microhardness tester (MH-5), respectively.

\section{Results and Discussion}

The EDS analysis reveals that the nitrogen partial pressure has a great effect on the ratio of $\mathrm{Zr} / \mathrm{Si}$ in $\mathrm{Zr}-\mathrm{Si}-\mathrm{N}$ films. Fig. 1 shows the definite relationship between $\mathrm{N}_{2}$ partial pressure and $\mathrm{Zr} / \mathrm{Si}$ ratio determined by EDS. The $\mathrm{Zr} / \mathrm{Si}$ ratio decreases with the increase of $\mathrm{N}_{2}$ partial pressure from 0.03 to $0.09 \mathrm{~Pa}$. This is related to the different sputtering rates of $\mathrm{Si}$ and its nitrides. The $\mathrm{Si}$ in a dominant form of low nitridation level would be re-sputtered away by the impinging particles more easily than that in the nitrided form ${ }^{[8]}$. As the $\mathrm{N}_{2}$ partial pressure increases the nitridation level of $\mathrm{Si}$ also increases, which could decrease the resputtering rate of silicon and result in high $\mathrm{Si}$ content.

Fig. 2 shows the XRD patterns of $\mathrm{Zr}-\mathrm{Si}-\mathrm{N}$ films. As $\mathrm{N}_{2}$ partial pressure increases, the intensity of $\mathrm{ZrN}$ (111) phase becomes weak gradually but the intensity of $\mathrm{ZrN}$ (220) increases. At low $\mathrm{N}_{2}$ partial pressure of $0.03 \mathrm{~Pa}, \mathrm{Zr}_{2} \mathrm{Si}$ (202) phase appears. The appearance of $\mathrm{Zr}_{2} \mathrm{Si}$ phase is related to the low nitridation level. With the increase of $\mathrm{N}_{2}$ partial pressure, $\mathrm{Zr}_{2} \mathrm{Si}$ phase disappears. There are only diffraction peaks of crystalline $\mathrm{ZrN}$ but no signals from crystalline $\mathrm{Si}_{3} \mathrm{~N}_{4}$ or from zirconium silicide can be observed at $\mathrm{N}_{2}$ partial pressure of 0.06 and $0.09 \mathrm{~Pa}$. This result shows that $\mathrm{Si}$ might be present in an amorphous phase of silicon nitride at higher $\mathrm{N}_{2}$ partial pressure.

The TEM examination of $\mathrm{Zr}-\mathrm{Si}-\mathrm{N}$ films indicates that the grain size in the films is very fine with $20 \mathrm{~nm}$ or less and changes little with the variation of $\mathrm{N}_{2}$ partial pressure.

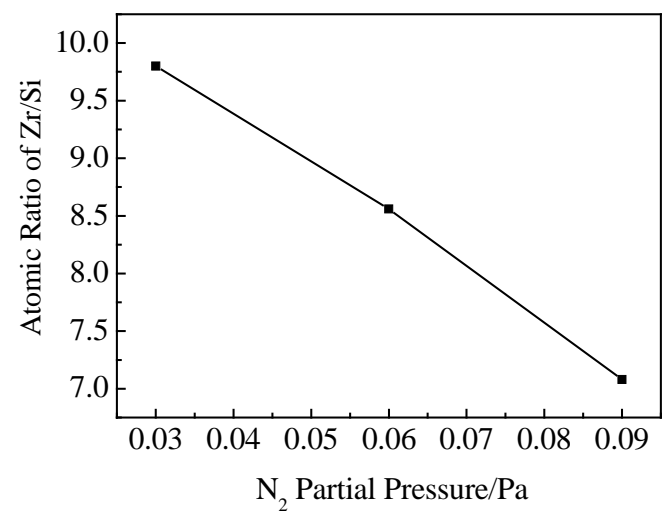

Fig.1 The $\mathrm{Zr} / \mathrm{Si}$ ratio in $\mathrm{Zr}-\mathrm{Si}-\mathrm{N}$ films sputtered with different $\mathrm{N}_{2}$ partial pressures

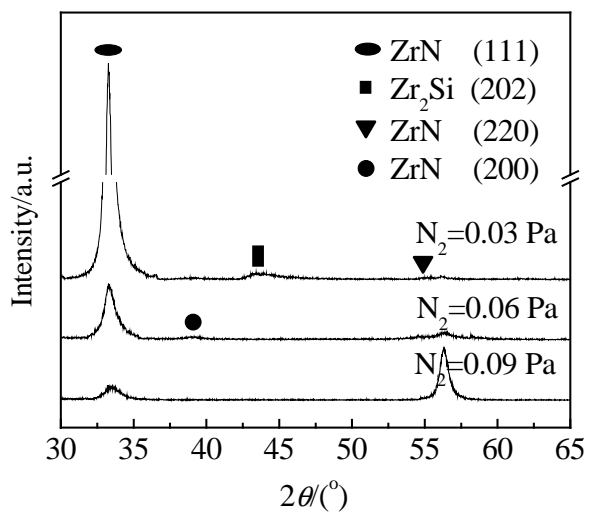

Fig.2 XRD patterns of $\mathrm{Zr}-\mathrm{Si}-\mathrm{N}$ films sputtered with different $\mathrm{N}_{2}$ partial pressures

Fig. 3 is the the TEM bright field (BF) image and electron diffraction (ED) patterns of Zr-Si-N films deposited with the $\mathrm{N}_{2}$ partial pressure of $0.09 \mathrm{~Pa}$. The diffraction rings can not be seen clearly from the ED patterns. This may be attributed to the very fine grains and amorphous $\mathrm{SiN}_{x}$ existing in the $\mathrm{Zr}-\mathrm{Si}-\mathrm{N}$ film.

The XPS analysis of the chemical state elements can characterize the phase composition in $\mathrm{Zr}-\mathrm{Si}-\mathrm{N}$ films. Fig.4a shows the $\mathrm{Zr} 3 \mathrm{~d}$ spectra in $\mathrm{Zr}-\mathrm{Si}-\mathrm{N}$ films. The peak binding energies of $\mathrm{Zr}-\mathrm{N}$ are consistent with the standard records of stoichiometric $\mathrm{ZrN}^{[9,10]}$. Fig.4b shows the Si $2 \mathrm{p}$ spectra in $\mathrm{Zr}-\mathrm{Si}-\mathrm{N}$ films, with the labeled values of standard binding energy of $\mathrm{Si}_{3} \mathrm{~N}_{4}$ and $\mathrm{Si}$. It is noticed that there are no XPS peaks of $\mathrm{Zr}$-Si bonding in the spectra. This may be the result of that the zirconium silicide existing in the $\mathrm{Zr}-\mathrm{Si}-\mathrm{N}$ films is very little. From Fig.4, it can be realized that the majority of $\mathrm{Si}$ exists in amorphous $\mathrm{SiN}_{x}$ phase in the Zr-Si-N films.

As a summary, the analyses of XRD, TEM and XPS indicate that the microstructures of $\mathrm{Zr}-\mathrm{Si}-\mathrm{N}$ films sputtered with different $\mathrm{N}_{2}$ partial pressures are composed of nano-crystallite $\mathrm{ZrN}$ embedded into amorphous matrix of

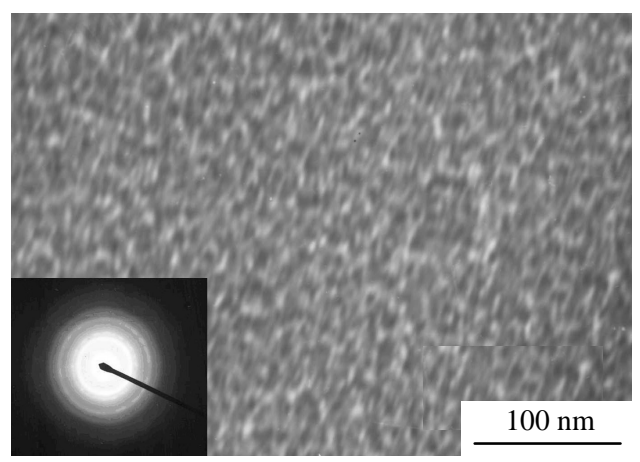

Fig.3 TEM images of $\mathrm{Zr}-\mathrm{SiN}$ films sputtered with the $\mathrm{N}_{2}$ partial pressure of $0.09 \mathrm{~Pa}$ 

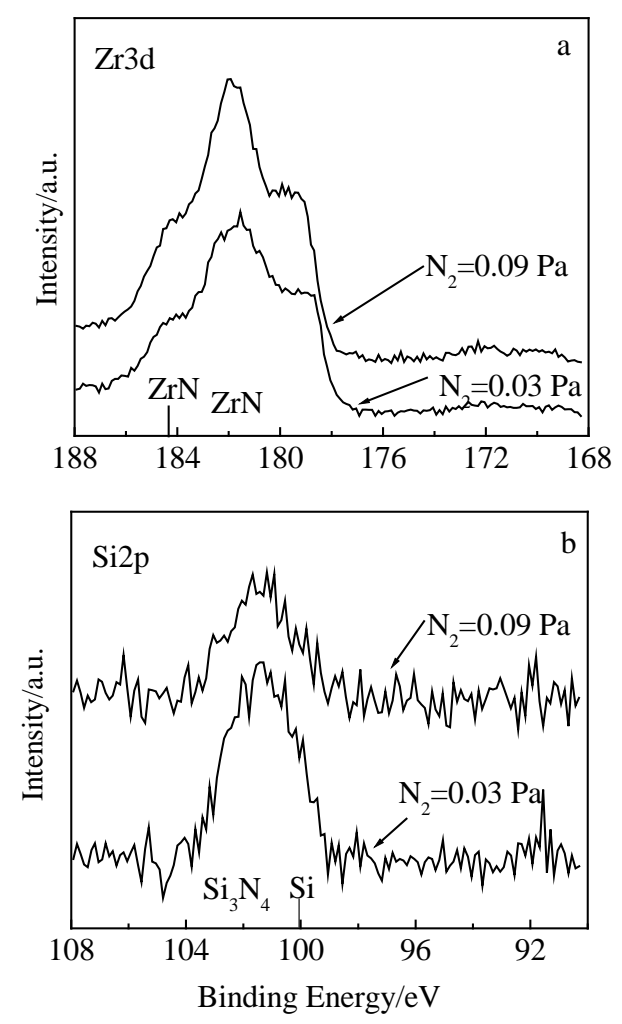

Fig.4 XPS spectra of Zr3d (a) and Si 2p (b) for Zr-Si-N films

$\mathrm{SiN}_{x}$ phase and a small quantity of $\mathrm{Zr}_{2} \mathrm{Si}$ produced at low $\mathrm{N}_{2}$ partial pressure. The appearance of $\mathrm{Zr}_{2} \mathrm{Si}$ phase is related to the low nitridation level.

Fig. 5 shows the relationship between the $\mathrm{N}_{2}$ partial pressures and the sheet resistances of $\mathrm{Zr}-\mathrm{Si}-\mathrm{N}$ films. It can be seen that the sheet resistance of $\mathrm{Zr}-\mathrm{Si}-\mathrm{N}$ films increases gradually as the $\mathrm{N}_{2}$ partial pressure increases. This is related with $\mathrm{Si}$ content of the film. The high $\mathrm{Si}$ content results in high resistivity of the film. The result is consistent with the similar research of Ta-Si-N films ${ }^{[11]}$.

Fig.6 illustrates that the microhardness of $\mathrm{Zr}-\mathrm{Si}-\mathrm{N}$ films decreases with the increase of $\mathrm{N}_{2}$ partial pressure. The microhardness reaches the maximum value of about $22.5 \mathrm{GPa}$ at the $\mathrm{N}_{2}$ partial pressure of $0.03 \mathrm{~Pa}$. Nose $\mathrm{M}$. et al ${ }^{[12]}$ investigated the relationship between the hardness of $\mathrm{Zr}-\mathrm{Si}-\mathrm{N}$ films and $\mathrm{Si}$ content. They reported that the hardness of $\mathrm{Zr}-\mathrm{Si}-\mathrm{N}$ films has a maximum value appearing at about $5 \%$ $\mathrm{Si}$, and then decreases gradually with the increase of $\mathrm{Si}$ content. This variation of hardness in Nose's experiment corresponds well to the change of residual stress and is interpreted in terms of lattice distortion by the addition of $\mathrm{Si}$. In our experiment, the $\mathrm{Si}$ content in all of the $\mathrm{Zr}-\mathrm{Si}$-N films is more than $5 \%$, and increases with the increase of $\mathrm{N}_{2}$ partial pressure (Fig.1). Therefore, according to the Nose's interpretation, the phenomenon that the microhardness of $\mathrm{Zr}-\mathrm{Si}-\mathrm{N}$ films decreases with the increase

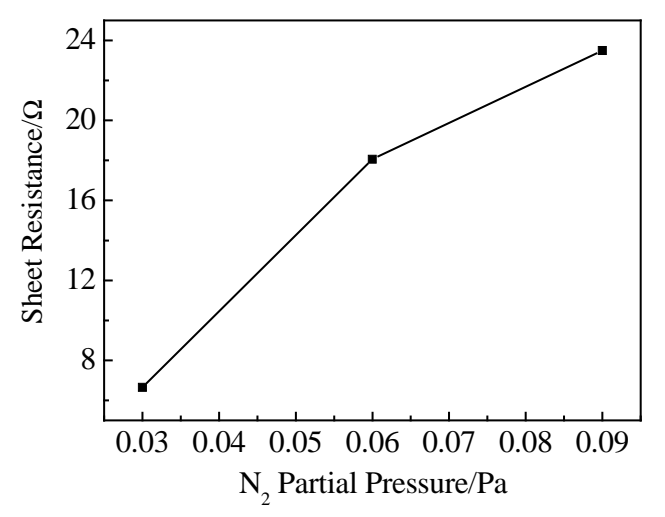

Fig.5 The sheet resistance of $\mathrm{Zr}-\mathrm{Si}-\mathrm{N}$ films sputtered with different $\mathrm{N}_{2}$ partial pressure

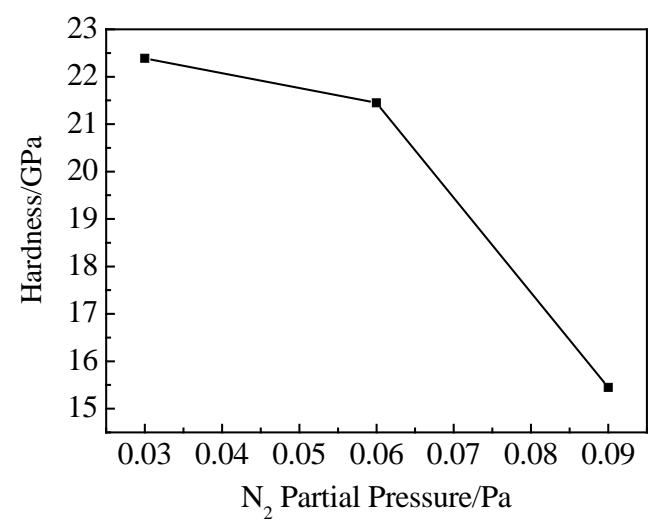

Fig.6 The microhardness of $\mathrm{Zr}-\mathrm{Si}-\mathrm{N}$ films sputtered with different $\mathrm{N}_{2}$ partial pressure

of $\mathrm{N}_{2}$ partial pressure in the present experiment may be related to the lattice distortion induced by the addition of $\mathrm{Si}$.

\section{Conclusions}

The microstructures of $\mathrm{Zr}-\mathrm{Si}-\mathrm{N}$ films are composed of nano-crystallite $\mathrm{ZrN}$ embedded into amorphous matrix of $\mathrm{SiN}_{x}$ phase and a small amount of $\mathrm{Zr}_{2} \mathrm{Si}$ produced at low $\mathrm{N}_{2}$ partial pressure. The appearance of $\mathrm{Zr}_{2} \mathrm{Si}$ phase is related to the low nitrogen activity. The grain size in the $\mathrm{Zr}-\mathrm{Si}-\mathrm{N}$ films is about $20 \mathrm{~nm}$ or less and changes little with the variation of $\mathrm{N}_{2}$ partial pressure. With the increase of $\mathrm{N}_{2}$ partial pressure, the $\mathrm{Zr} / \mathrm{Si}$ ratio decreases and the sheet resistance increases. At the $\mathrm{N}_{2}$ partial pressure of $0.03 \mathrm{~Pa}$, the microhardness of $\mathrm{Zr}-\mathrm{Si}-\mathrm{N}$ film reaches the maximum value of about $22.5 \mathrm{GPa}$.

\section{References}

1 Hultman L. Vacuum[J], 2000, 57(1): 1

2 Feng C, Zhu S, Li M et al. Surface and Coatings Technology[J], 2008, 202: 3257 
Wang Jinafeng et al. / Rare Metal Materials and Engineering, 2009, 38(5): 0753-0756

3 Ee Y C, Chen Z, Law S B et al. Applied Surface Science [J], 2006, 253: 530

4 Hubner R, Hecker M, Mattern N et al. Thin Solid Films[J], 2006, 500: 259

5 Veprek S, Reiprich S. Thin Solid Films[J], 1995, 268(1 2): 64

6 Wang Y, Zhao C, Cao F et al. Materials Letters[J], 2008, 62: 2289

7 Daniel R, Musil J, Zeman P et al. Surface and Coatings Technology[J], 2006, 201: 3368

8 Diserens M, Patscheider J, Lévy F. Surface and Coatings Tech-
nology[J], 1998, 109(1 3): 241

9 Netterfield R P, Martin P J, Mckenzie D R. Journal of Materials Science Letters [J], 1990, 9(8): 972

10 Milosev I, Strehblow H H, Navinsek B. Thin Solid Films [J], 1997, 303(1 2): 246

11 Olowolafe J O, Rau I, Unruh K M et al. Thin Solid Films [J], 2000, 365(1): 19

12 Nose M, Zhou M, Nagae T et al. Surface and Coatings Technology[J], 2000, 132(2 3): 163

\title{
不同氮分压制备纳米复合 Zr-Si-N 薄膜的组织与性能研究
}

\author{
王剑锋 ${ }^{1}$, 马大衍 ${ }^{1}$, 宋忠孝 ${ }^{1}$, 唐 武 $^{2}$, 徐可为 ${ }^{1}$
}

(1. 西安交通大学 金属强度国家重点实验室，陕西 西安 710049)

(2. 电子科技大学 电子薄膜与集成器件国家重点实验室, 四川 成都 610054)

\begin{abstract}
摘 要: 利用射频反应磁控㳚射设备在不同 $\mathrm{N}_{2}$ 分压下制备了 $\mathrm{Zr}-\mathrm{Si}-\mathrm{N}$ 纳米复合薄膜。研究了 $\mathrm{N}_{2}$ 分压对薄膜组织和性能的影响。结果表 明：随着 $\mathrm{N}_{2}$ 分压的增加，薄膜中 $\mathrm{Zr} 、 \mathrm{Si}$ 元素含量比降低，且薄膜方电阻增加; $\mathrm{Zr}-\mathrm{Si}-\mathrm{N}$ 薄膜的微观组织由纳米晶 $\mathrm{ZrN}$ 嵌入 $\mathrm{SiN}_{x}$ 非晶基 体构成, 在低 $\mathrm{N}_{2}$ 分压条件下, 有少量 $\mathrm{Zr}_{2} \mathrm{Si}$ 形成。 $\mathrm{Zr}_{2} \mathrm{Si}$ 的形成与低 $\mathrm{N}$ 反应活性相关。在 $0.03 \mathrm{~Pa} \mathrm{~N}_{2}$ 分压条件下, $\mathrm{Zr}-\mathrm{SiN}$ 薄膜硬度达 到 $22.5 \mathrm{GPa}$ 的最大值。高 $\mathrm{N}_{2}$ 分压制备薄膜硬度较低可能与 $\mathrm{Si}$ 原子造成的晶格畸变相关。
\end{abstract}

关键词: Zr-SiN 薄膜; 磁控浌射; 微观组织; 性能

作者简介: 王剑锋, 男, 1979 年生, 博士生, 西安交通大学金属材料强度国家重点实验室, 陕西 西安 710049, 电话: 029-82668614,

E-mail: wangjianfeng@mail.xjtu.edu.cn; 通讯作者: 马大衍, E-mail: madayan@mail.xjtu.edu.cn 